\title{
Sociodemographic and economic factors are associated with weight gain between before and after cancer diagnosis: results from the prospective population-based NutriNet-Santé cohort
}

\author{
Philippine Fassier ${ }^{1}$, Laurent Zelek ${ }^{1,2}$, Patrick Bachmann ${ }^{3}$, Marina Touillaud ${ }^{3}$, \\ Nathalie Druesne-Pecollo ${ }^{1}$, Valentin Partula ${ }^{1}$, Serge Hercberg ${ }^{1,4}$, Pilar Galan ${ }^{1}$, \\ Patrice Cohen ${ }^{5}$, Hélène Hoarau ${ }^{5}$, Paule Latino-Martel ${ }^{1}$, Bernard Srour ${ }^{1}$, Rebeca \\ Gonzalez $^{1}$, Mélanie Deschasaux ${ }^{1}$ and Mathilde Touvier ${ }^{1}$ \\ ${ }^{1}$ Nutritional Epidemiology Research Team (EREN): Inserm U1153, Inra U1125, Cnam, Paris 5, 7 and 13 Universities, Sorbonne \\ Paris Cité Epidemiology and Statistics Research Center, F-93017, Bobigny, France \\ ${ }^{2}$ Oncology Department, Avicenne Hospital, F-93017, Bobigny, France \\ ${ }^{3}$ Cancer, Environment and Nutrition Unit, Léon Bérard Center, F-69000, Lyon, France \\ ${ }^{4}$ Public Health Department, Avicenne Hospital, F-93017, Bobigny, France \\ ${ }^{5}$ Sociology Department, University of Rouen, DySola, EA 4701, F-76821, Rouen, France \\ Correspondence to: Philippine Fassier, email: p.fassier@eren.smbh.univ-paris13.fr \\ Keywords: weight gain, weight loss, cancer diagnosis, breast cancer, socio-demographic factors \\ Abbreviations: BMI: body mass index; OR: odds ratio; Cl: confidence interval \\ Received: November 25, $2016 \quad$ Accepted: March 27, $2017 \quad$ Published: May 08, 2017 \\ Copyright: Fassier et al. This is an open-access article distributed under the terms of the Creative Commons Attribution License 3.0 \\ (CC BY 3.0), which permits unrestricted use, distribution, and reproduction in any medium, provided the original author and source \\ are credited.
}

\section{ABSTRACT}

Purpose: While many cancer patients are affected by weight loss, others tend to gain weight, which may impact prognosis and risk of recurrence and of second cancer. The aim of this prospective study was to investigate weight variation between before and after cancer diagnosis and socio-demographic, economic, lifestyle and clinical factors associated with moderate-to-severe weight gain.

Methods: 1051 incident cases of first primary cancer were diagnosed in the NutriNet-Santé cohort between 2009 and 2015. Weight was prospectively collected every 6 months since subjects' inclusion (i.e. an average of $2 y$ before diagnosis). Mean weights before and after cancer diagnosis were compared with paired Student's t-test. Factors associated with moderate-to-severe weight gain ( $\geq 5 \%$ of initial weight) were investigated by age and sex-adjusted logistic regression.

Results: Weight loss was observed in men $(-3.54 \pm 4.39 \mathrm{~kg}$ in those who lost weight, $p=0.0002)$ and in colorectal cancer patients $(-3.94 \pm 4.40 \mathrm{~kg}, \mathrm{p}=0.001)$. Weight gain was observed in breast and skin cancers $(2.83 \pm 3.21 \mathrm{~kg}, \mathrm{p}=0.04$, and $2.96 \pm 2.75 \mathrm{~kg}, \mathrm{p}=0.04$ respectively). Women $(O R=1.75[1.06-2.87], p=0.03)$, younger patients $(2.44$ [1.51$3.70], p<0.0001)$, those with lower income $(O R=1.30[1.01-1.72]$, $p$-trend $=0.007)$, lower education $(\mathrm{OR}=1.32[1.03-2.70], \mathrm{p}$-trend $=0.03)$, excess weight before diagnosis $(O R=1.64[1.12-2.42], p=0.01)$, lower physical activity $(O R=1.28[1.01-1.64], p=0.04)$ and those who stopped smoking $(\mathrm{OR}=4.31[1.99-9.35], \mathrm{p}=0.005])$ were more likely to gain weight. In breast cancer patients, induced menopause was associated with weight gain $(O R=4.12[1.76-9.67])$, but no association was detected for tumor characteristics or treatments.

Conclusion: This large prospective cohort provided original results on weight variation between before and after cancer diagnosis, highlighting different weight 


\section{trajectories. Socio-demographic and economic factors appeared to influence the risk of weight gain, illustrating social inequalities in health.}

\section{INTRODUCTION}

More than 14 million of new cancer cases have been diagnosed in 2012 worldwide [1]. Due to the impact on physical, psychological and social functions of cancer itself and of secondary effects of anticancer therapies, malnutrition and weight loss are widespread in cancer patients [2-5]. A recent review showed that unintentional weight loss is a common issue in colorectal cancer patients [6]. In a recent French survey, 52\% of patients with colorectal, pancreatic or gastric cancer experienced malnutrition [2]. Cancer-associated malnutrition has also been observed for non-digestive cancer locations [2, 4].

In contrast, weight gain has been described in many patients, especially in women diagnosed with breast cancer [7-13]. Weight gain has also been observed in prostate cancer patients who followed androgen deprivation therapy $[14,15]$. Weight gain after breast and prostate cancer diagnosis is an important risk factor for poorer prognosis and recurrence [16-21], while weight management appears as a key component of tertiary prevention [22, 23]. In addition, in a recent meta-analysis, we showed that excess body weight at the diagnosis of a first breast cancer was associated with increased risk of second primary breast, endometrial and colorectal cancers [24]. Excess weight after diagnosis is also associated with higher all-cause mortality [21].

Since weight gain is a modifiable risk factor, some studies intended to identify its predictors in cancer patients $[8-11,13,14]$. Several factors have been suggested to influence weight gain after diagnosis including age [10, 11, 13, 14], educational level [11, 13], initial Body Mass Index (BMI) [11, 13], physical activity [25], energy intake $[9,10]$, smoking status $[10]$, menopausal status and hormone receptors' status for breast cancer [10], disease stage $[10,13]$ and cancer-related treatments $[8$, 12-14, 26-29]. However, these studies had limitations. They mostly focused on weight variation after cancer diagnosis and thus did not collect data regarding weight before diagnosis $[2,8,14,15,25]$. Few studies provided weight information before diagnosis, but all relied on prediagnosis anthropometric data collected retrospectively [9-11, 13]. To our knowledge, no study investigated weight change between before and after cancer diagnosis with anthropometric data collected prospectively, which would lower memory bias and substantially increase data quality. In addition, very few studies investigated a wide range of potential predictors of weight variation in the same dataset $[10,13,25]$.

The aim of this study was to quantify weight variation (overall and by sex, cancer location and cancer prognosis) between before and after cancer diagnosis in a large cohort, relying on prospective anthropometric data. We also investigated socio-demographic, economic, lifestyle and clinical factors associated with moderate-tosevere weight gain.

\section{RESULTS}

Characteristics of the study population are presented in Table 1 and Table $2.68 \%$ of subjects were women. Mean age at diagnosis was $58 \pm 10.9$ years. $40.1 \%$ had excess weight before cancer diagnosis. Mean time between inclusion in the cohort and diagnosis was $24.6 \pm 14.7$ months. Main cancer locations were: breast $(37 \%)$, prostate $(15 \%)$, skin $(10 \%)$ and colon-rectum $(7 \%)$. Sex and age at diagnosis were similar between included and excluded cases ( $\mathrm{p}=0.6$ and 0.3 respectively) but breast and prostate cancers were more frequent in included cases $(\mathrm{p}=0.0007)$. Mean weight before $(\mathrm{p}=0.4)$ and respectively after $(p=0.7)$ cancer diagnosis were similar between included and excluded cases with available weight data (375 excluded cases had weight data before diagnosis and 20 after respectively) (Appendix 1).

The weight values before diagnosis were not statistically different $(p=0.2)$. Similarly there was no difference between weight values after cancer diagnosis $(\mathrm{p}=0.9)$ (data not shown).

Weight variations between before and after cancer diagnosis are described in Table 3. Overall, no weight variation was observed $(\mathrm{p}=0.08)$ (relative difference $=-0.22 \%, 95 \%$ confidence Interval $=[-0.59$; $0.16])$. However, weight variation was significantly different between sex and cancer location $(\mathrm{p}=0.0003$ and $<0.0001$ respectively): Weight loss was observed in men ( $\mathrm{p}=0.0002$, mean weight loss in men who lost weight $=-3.54 \pm 4.39 \mathrm{~kg})$ and patients with colorectal cancer ( $\mathrm{p}=0.001$, mean weight loss in patients who lost weight $=-3.94 \pm 4.40 \mathrm{~kg})$. In contrast, weight gain was observed in breast and skin cancer patients $(\mathrm{p}=0.04$, mean weight gain $=2.83 \pm 3.21 \mathrm{~kg}$ and $\mathrm{p}=0.04$, mean weight gain $=2.96 \pm 2.75 \mathrm{~kg}$ respectively). In breast and skin cancer patients, moderate-to-severe weight gain $(15.6 \%$ for breast and $17.9 \%$ for skin cancers) was more frequent than moderate-to-severe weight loss $(12.5 \%$ for breast and $8.5 \%$ for skin cancers).

Associations between moderate-to-severe weight gain and socio-demographic, economic and lifestyle factors are presented in Table 4. Women $\left(\mathrm{OR}_{\text {women }}\right.$ $\left.{ }_{\text {men }}=1.75,95 \% \mathrm{CI}: \quad[1.06-2.87], \quad \mathrm{p}=0.03\right)$, younger patients $\quad\left(\mathrm{OR}_{\leq 60 \text { years }>60}=2.44[1.51-3.70], \quad \mathrm{p}<0.0001\right)$, those with lower monthly income $\left(\mathrm{OR}_{<1800 €}\right.$ per household unit vs $\left.>2700 e=1.30[1.01-1.72], \mathrm{p}_{\text {trend }}=0.007\right)$ lower educational level $\left(\mathrm{OR}_{\mathrm{no}}\right.$ higher education vs post-graduate $=1.32[1.03-2.70]$, $\left.\mathrm{p}_{\text {trend }}=0.03\right)$, those with excess weight before cancer diagnosis $\left(\mathrm{OR}_{\text {yes vs no }}=1.64[1.12-2.42], \mathrm{p}=0.01\right)$, who 
Table 1: Sociodemographic, economic and lifestyle characteristics of first incident cancer cases of the NutriNet-Santé cohort, 2009-2015 $(\mathrm{N}=1051)^{1}$

\begin{tabular}{|c|c|c|c|c|}
\hline & $\mathbf{N}$ & $\%$ & Mean & SD \\
\hline Age at diagnosis (years) & & & 58.5 & 10.9 \\
\hline $\begin{array}{l}\text { Mean BMI before cancer } \\
\text { diagnosis }\left(\mathrm{kg} / \mathrm{m}^{2}\right)\end{array}$ & & & 24.9 & 4.8 \\
\hline $\begin{array}{l}\text { Mean BMI after cancer } \\
\text { diagnosis }\left(\mathrm{kg} / \mathrm{m}^{2}\right)\end{array}$ & & & 24.8 & 4.9 \\
\hline $\begin{array}{l}\text { Time between inclusion } \\
\text { in the cohort and cancer } \\
\text { diagnosis (months) }\end{array}$ & & & 24.6 & 14.7 \\
\hline \multicolumn{5}{|l|}{ Sex } \\
\hline Male & 339 & 32.2 & & \\
\hline Female & 712 & 67.8 & & \\
\hline
\end{tabular}

Living area in

Metropolitan France ${ }^{2}$

Paris or Paris suburb

North / North-East

North-West

Center

South-East

South-West

Professionally active ${ }^{2}$

\section{No}

Yes

Monthly income (€per household unit) ${ }^{2}$

$$
\begin{aligned}
& <1800 \\
& 1800-2700 \\
& >2700
\end{aligned}
$$

Smoker after cancer diagnosis
44.8

55.2

36.2

29.1

34.7

43.9

27.3

28.8

88.5

91 8.6

(Continued) 


\begin{tabular}{|c|c|c|c|c|}
\hline & $\mathbf{N}$ & $\%$ & Mean & SD \\
\hline \multicolumn{5}{|l|}{$\begin{array}{l}\text { Excess weight } t^{3} \text { before } \\
\text { cancer diagnosis }\end{array}$} \\
\hline No & 630 & 59.9 & & \\
\hline Yes & 421 & 40.1 & & \\
\hline \multicolumn{5}{|l|}{$\begin{array}{l}\text { Physical activity after } \\
\text { cancer diagnosis }\end{array}$} \\
\hline $\begin{array}{l}\text { Physically active } \\
\text { (moderate-to-intense) }\end{array}$ & 650 & 78.1 & & \\
\hline Low physical activity & 182 & 21.9 & & \\
\hline \multicolumn{5}{|l|}{$\begin{array}{l}\text { Energy intake variation } \\
\text { before / after cancer } \\
\text { diagnosis }\end{array}$} \\
\hline$<-100 \mathrm{kcal} /$ day & 294 & 44.0 & & \\
\hline$[-100-+100] \mathrm{kcal} /$ day & 158 & 23.6 & & \\
\hline$>+100 \mathrm{kcal} /$ day & 217 & 32.4 & & \\
\hline
\end{tabular}

${ }^{1}$ Multiple imputation was applied for missing data on covariates ( $\mathrm{N}=382$ for energy intake variation, $\mathrm{N}=219$ for physical activity, $\mathrm{N}=62$ for monthly income, $\mathrm{N}=5$ for educational level).

${ }^{2}$ At baseline, i.e. at inclusion in the NutriNet-Santé cohort study.

${ }^{3} \mathrm{BMI} \geq 25 \mathrm{~kg} / \mathrm{m}^{2}$.

${ }^{4}$ From the validated IPAQ questionnaire.

Table 2: Cancer location and prognosis of first incident cancer cases of the NutriNet-Santé cohort, 2009-2015 $(\mathrm{N}=1051)^{1}$

\begin{tabular}{lcccccccc}
\hline & Breast $^{2}$ & $(\mathbf{N}=\mathbf{3 8 5})$ & \multicolumn{2}{c}{ Prostate $^{3}$} & $(\mathbf{N}=\mathbf{1 6 2})$ & \multicolumn{2}{c}{ Skin $^{4}(\mathbf{N}=\mathbf{1 0 6})$} & \multicolumn{2}{c}{ Colon-rectum $^{\mathbf{5}}(\mathbf{N}=\mathbf{7 4})$} \\
\hline & $\mathbf{N}$ & $\mathbf{\%}$ & $\mathbf{N}$ & $\mathbf{\%}$ & $\mathbf{N}$ & $\mathbf{\%}$ & $\mathbf{N}$ & $\mathbf{\%}$ \\
\hline $\begin{array}{l}\text { Favorable } \\
\text { prognosis }\end{array}$ & 216 & 56.1 & 60 & 37.04 & 24 & 22.64 & 13 & 17.57 \\
$\begin{array}{l}\text { Poor } \\
\text { prognosis }\end{array}$ & 120 & 31.17 & 54 & 33.33 & 81 & 76.42 & 41 & 55.41 \\
$\begin{array}{l}\text { Missing } \\
\text { data }\end{array}$ & 49 & 12.73 & 48 & 29.63 & 1 & 0.94 & 20 & 27.03 \\
\hline
\end{tabular}

${ }^{1}$ Multiple imputation was applied for missing data on covariates $(\mathrm{N}=49$ for breast cancer, $\mathrm{N}=48$ for prostate cancer, $\mathrm{N}=1$ for skin cancer, $\mathrm{N}=20$ for colon-rectum cancer), we have applied multiple imputation.

${ }^{2}$ Tumor size $<2 \mathrm{~cm}$ or node-negative or (tumor size $<1 \mathrm{~cm}$ and negative ER/PR receptors) = favorable prognosis; tumor size $\geq 2 \mathrm{~cm}$ or node-positive or (tumor size $\geq 1 \mathrm{~cm}$ and positive $\mathrm{ER} / \mathrm{PR}$ receptors) $=$ poor prognosis.

${ }^{3} \mathrm{PSA} \leq 20 \mathrm{ng} / \mathrm{ml}$ or Gleason $\leq 7$ or cancer $\leq \mathrm{T} 2 \mathrm{~b}=$ favorable prognosis; PSA $>20 \mathrm{ng} / \mathrm{ml}$ or Gleason $>7$ or cancer $>\mathrm{T} 2 \mathrm{~b}=$ poor prognosis.

${ }^{4}$ Squamous cell carcinoma $=$ favorable prognosis; melanoma $=$ poor prognosis.

${ }_{5}^{5}$ (Cancer T1/T2 and node-negative) or no chemotherapy = favorable prognosis; (cancer T3/T4 and node-positive) or chemotherapy $=$ poor prognosis. 
Appendix 1: Comparison between included and excluded cancer cases, NutriNet-Santé cohort, 2009-2015

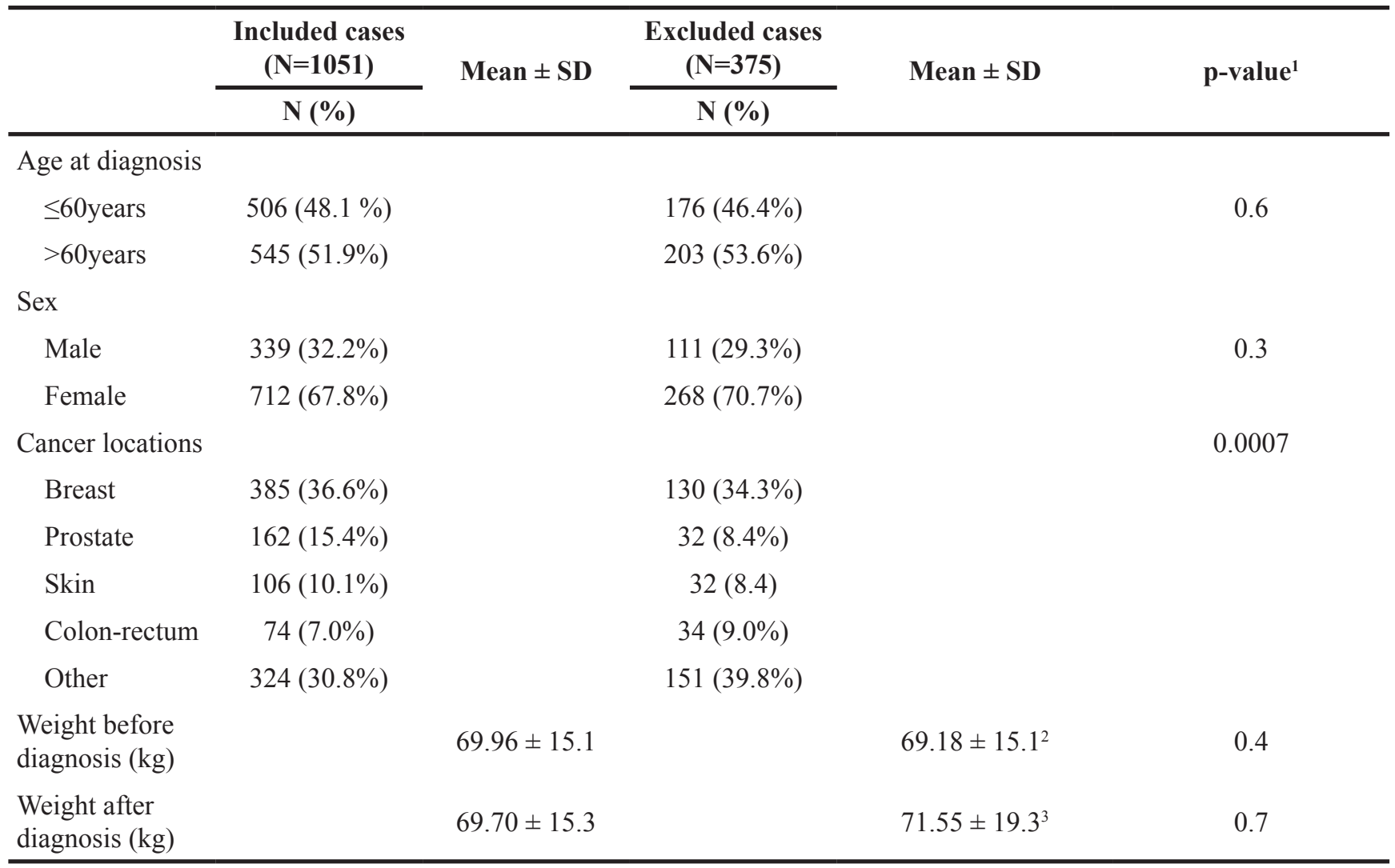

${ }^{1} \mathrm{P}$-value of Student t-test for continuous variables and Chi-square test for qualitative variables.

${ }^{2}$ Available for 375 excluded cases.

${ }^{3}$ Available for 20 excluded cases.

practiced lower physical activity after diagnosis $\left(\mathrm{OR}_{\text {low }}\right.$ physical activity vs moderante-to-intense physical activity $=1.28 \quad[1.01-1.64]$, $\mathrm{p}=0.04)$ and patients who stopped smoking after diagnosis $\left(\mathrm{OR}_{\text {stopped smoking vs never smoked }}=4.31[1.99-9.35\right.$, $\mathrm{p}=0.005])$ were more likely to gain weight. Similar trends were observed in breast cancer patients, although some results were not significant due to reduced statistical power (Table 4). No association was found among skin cancers $(\mathrm{p}>0.05)$ (Table 4$)$.

No interaction was observed between cancer prognosis and socio-demographic, economic and lifestyle factors (all $\mathrm{p}>0.10$ ) excepted for breast cancer cases for which an interaction was found between cancer prognosis and income $(\mathrm{p}=0.07)$. However, in stratified analysis, the association between monthly income and weight variation was non-statistically significant in both strata of cancer prognosis $(\mathrm{p}>0.05)$.

Results were similar when all factors of Table 4 were entered simultaneously into the model, except for monthly income and educational level which became nonstatistically significant due to their strong correlation with other sociodemographic factors
The following clinical parameters were not associated with moderate-to-severe weight gain in female breast cancer patients: tumor size $(p=0.9)$, lymph node status $(p=0.6)$, tumor type $(p=0.3)$, estrogen receptor $(p=0.1)$, progesterone receptor $(p=0.8)$, HER2 status $(p=0.5), \operatorname{Ki67}(p=0.3)$, chemotherapy $(p=0.5)$, hormone therapy $(p=0.6)$, indicator of cancer severity $(p=0.7)$, menopausal status $(p=0.3)$ and cause of menopause $(\mathrm{p}=0.5)$. However women with induced menopause were more likely to experience moderate-tosevere weight gain $(\mathrm{OR}=4.12[1.76-9.67], \mathrm{p}=0.001)$ (data not shown).

In sensitivity analyses, all results were similar when excluding subjects who had a second primary cancer or cancer recurrence during follow-up $(n=37)$. Similar trends were observed when excluding anthropometric data collected less than 1 year or 2 years after cancer diagnosis, although some results became non-significant, due to loss of statistical power $(n=855$ and $n=524$ remaining subjects with available weight data respectively, data not shown). 
Table 3: Weight variation between before and after cancer diagnosis, NutriNet-santé cohort 2009-2015 ( $N=1051)$

\begin{tabular}{|c|c|c|c|c|c|c|c|c|c|c|}
\hline & \multicolumn{6}{|c|}{ Weight variation between before and after cancer diagnosis } & \multicolumn{4}{|c|}{$\begin{array}{c}\text { Moderate-to-severe weight variation ( } \geq 5 \% \text { of } \\
\text { initial weight) }\end{array}$} \\
\hline & $\begin{array}{c}\text { Relative } \\
\text { difference }^{1}\end{array}$ & $95 \%$ CI & p-value ${ }^{2}$ & $\begin{array}{l}\text { p-value } \\
\text { for the } \\
\text { difference } \\
\text { between } \\
\text { classes }^{3}\end{array}$ & $\begin{array}{c}\text { Weight loss } \\
\text { in patients } \\
\text { who lost } \\
\text { weight }\end{array}$ & $\begin{array}{c}\begin{array}{c}\text { Weight } \\
\text { gain in } \\
\text { patients } \\
\text { who gained } \\
\text { weight }\end{array} \\
\text { Mean } \pm \text { SD }\end{array}$ & $\begin{array}{c}\text { Moderate- } \\
\text { to-severe } \\
\text { weight loss } \\
(\%)\end{array}$ & $\begin{array}{c}\text { No weight } \\
\text { variation } \\
(\%)\end{array}$ & $\begin{array}{l}\text { Moderate- } \\
\text { to-severe } \\
\text { weight } \\
\text { gain }(\%)\end{array}$ & $\begin{array}{l}\text { p-value } \\
\text { for the } \\
\text { difference } \\
\text { between } \\
\text { classes }^{4}\end{array}$ \\
\hline Overall & -0.22 & {$[-0.59 ; 0.16]$} & 0.08 & & $-3.37 \pm 4.19$ & $2.75 \pm 3.08$ & 15.2 & 72.3 & 12.5 & \\
\hline Sex & & & & 0.0003 & & & & & & 0.005 \\
\hline Male & -1.25 & {$[-1.87 ;-0.62]$} & 0.0002 & & $-3.54 \pm 4.39$ & $2.50 \pm 3.49$ & 15.3 & 77.9 & 6.8 & \\
\hline Female & 0.27 & {$[-0.19 ; 0.73]$} & 0.6 & & $-3.26 \pm 4.06$ & $2.84 \pm 2.93$ & 15.2 & 69.6 & 15.2 & \\
\hline $\begin{array}{l}\text { Main cancer } \\
\text { locations }\end{array}$ & & & & $<0.0001$ & & & & & & $<0.0001$ \\
\hline Breast $^{5}$ & 0.67 & {$[0.09 ; 1.26]$} & 0.04 & & $-2.90 \pm 2.69$ & $2.83 \pm 3.21$ & 12.5 & 71.9 & 15.6 & \\
\hline $\begin{array}{l}\text { Favorable } \\
\text { prognosis }\end{array}$ & 0.75 & {$[0.17 ; 1.72]$} & 0.02 & & $-2.90 \pm 2.78$ & $2.84 \pm 3.43$ & 10.3 & 75.4 & 14.3 & \\
\hline $\begin{array}{l}\text { Poor } \\
\text { prognosis }\end{array}$ & 0.19 & {$[-0.75 ; 1.14]$} & 0.7 & & $-3.04 \pm 2.65$ & $2.91 \pm 2.66$ & 16.3 & 65.7 & 18.0 & \\
\hline $\begin{array}{l}\text { p-value } \\
\text { between } \\
\text { cancer } \\
\text { prognosis }\end{array}$ & 0.2 & & & & & & & & & \\
\hline Prostate $^{6}$ & -0.18 & {$[-0.87 ; 0.51]$} & 0.5 & & $-2.00 \pm 2.74$ & $2.13 \pm 3.06$ & 5.6 & 88.8 & 5.6 & \\
\hline $\begin{array}{l}\text { Favorable } \\
\text { prognosis }\end{array}$ & -0.57 & {$[-1.48 ; 0.33]$} & 0.2 & & $-2.17 \pm 2.68$ & $1.57 \pm 1.72$ & 5.3 & 91.8 & 2.9 & \\
\hline $\begin{array}{l}\text { Poor } \\
\text { prognosis }\end{array}$ & 0.16 & {$[-1.03 ; 1.35]$} & 0.8 & & $-2.18 \pm 3.02$ & $2.52 \pm 3.34$ & 5.9 & 85.7 & 8.4 & \\
\hline $\begin{array}{l}\text { p-value } \\
\text { between } \\
\text { cancer } \\
\text { prognosis }\end{array}$ & 0.4 & & & & & & & & & \\
\hline Skin $^{7}$ & 1.16 & {$[0.18 ; 2.13]$} & 0.04 & & $-2.25 \pm 2.22$ & $2.96 \pm 2.75$ & 8.5 & 73.6 & 17.9 & \\
\hline $\begin{array}{l}\text { Favorable } \\
\text { prognosis }\end{array}$ & 0.24 & {$[-1.38 ; 1.87]$} & 0.7 & & $-2.12 \pm 2.85$ & $3.01 \pm 2.30$ & 16.7 & 70.8 & 12.5 & \\
\hline $\begin{array}{l}\text { Poor } \\
\text { prognosis }\end{array}$ & 1.33 & {$[0.15 ; 2.51]$} & 0.04 & & $-2.21 \pm 1.98$ & $3.0 \pm 2.90$ & 8.6 & 72.8 & 18.5 & \\
\hline $\begin{array}{l}\text { p-value } \\
\text { between } \\
\text { cancer } \\
\text { prognosis }^{9}\end{array}$ & 0.2 & & & & & & & & & \\
\hline $\begin{array}{l}\text { Colon- } \\
\text { rectum }\end{array}$ & -2.21 & {$[-3.55 ;-0.88]$} & 0.001 & & $-3.94 \pm 4.40$ & $1.93 \pm 1.18$ & 23.0 & 74.3 & 2.7 & \\
\hline $\begin{array}{l}\text { Favorable } \\
\text { prognosis }\end{array}$ & -0.54 & {$[-2.99 ; 1.92]$} & 0.7 & & $-3.24 \pm 3.66$ & $2.36 \pm 1.46$ & 15.4 & 77.2 & 15.4 & \\
\hline $\begin{array}{l}\text { Poor } \\
\text { prognosis }\end{array}$ & -2.99 & {$[-4.63 ;-1.34]$} & 0.0004 & & $-4.40 \pm 4.34$ & $1.40 \pm 1.21$ & 26.9 & 71.0 & 2.1 & \\
\hline $\begin{array}{l}\text { p-value } \\
\text { between } \\
\text { cancer } \\
\text { prognosis }\end{array}$ & 0.2 & & & & & & & & & \\
\hline
\end{tabular}

${ }^{1}$ Relative difference $=($ mean weight after diagnosis mean weight before diagnosis $) /$ mean weight before diagnosis $* 100$.

${ }^{2}$ Paired Student's t-test comparing mean weight before and mean weight after cancer diagnosis.

${ }^{3}$ ANOVA test.

${ }^{4}$ Chi-square test.

${ }^{5}$ Tumor size $<2 \mathrm{~cm}$ or node-negative or (tumor size $<1 \mathrm{~cm}$ and negative ER/PR receptors) = favorable prognosis; tumor size $\geq 2 \mathrm{~cm}$ or node-positive or (tumor size $\geq 1 \mathrm{~cm}$ and positive $\mathrm{ER} / \mathrm{PR}$ receptors) = poor prognosis.

${ }^{6} \mathrm{PSA} \leq 20 \mathrm{ng} / \mathrm{ml}$ or Gleason $\leq 7$ or cancer $\leq \mathrm{T} 2 \mathrm{~b}=$ favorable prognosis; $\mathrm{PSA}>20 \mathrm{ng} / \mathrm{ml}$ or Gleason $>7$ or cancer $>\mathrm{T} 2 \mathrm{~b}=$ poor prognosis.

${ }^{7}$ Squamous cell carcinoma $=$ favorable prognosis; Melanoma $=$ poor prognosis.

${ }^{8}$ (Cancer T1/T2 and node-negative) or no chemotherapy = favorable prognosis; (CancerT3/T4 and node-positive) or chemotherapy $=$ poor prognosis.

${ }^{9}$ Student's t-test. 
Table 4: Socio-demographic, economic and lifestyle factors associated with moderate-to-severe weight gain ${ }^{1}$ between $^{2}$ before and after cancer diagnosis, by unconditional logistic regression analyses, NutriNet-Santé cohort, 2009-2015 $(\mathrm{N}=\mathbf{1 0 5 1})$

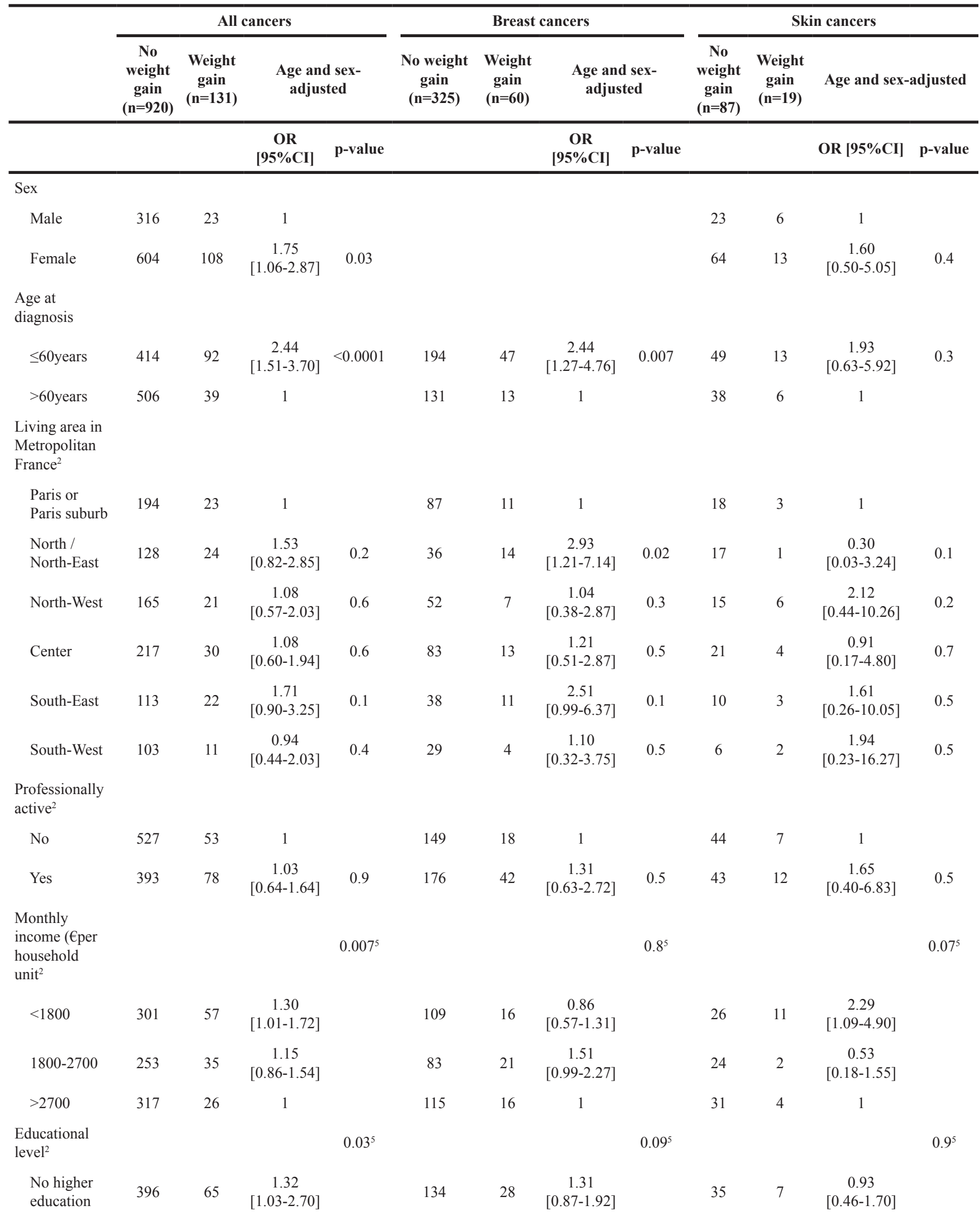

(Continued) 


\begin{tabular}{|c|c|c|c|c|c|c|c|c|c|c|c|c|}
\hline & \multicolumn{4}{|c|}{ All cancers } & \multicolumn{4}{|c|}{ Breast cancers } & \multicolumn{4}{|c|}{ Skin cancers } \\
\hline & $\begin{array}{c}\text { No } \\
\text { weight } \\
\text { gain } \\
(n=920)\end{array}$ & $\begin{array}{c}\text { Weight } \\
\text { gain } \\
(n=131)\end{array}$ & \multicolumn{2}{|c|}{$\begin{array}{l}\text { Age and sex- } \\
\text { adjusted }\end{array}$} & $\begin{array}{c}\text { No weight } \\
\text { gain } \\
(n=325)\end{array}$ & $\begin{array}{c}\text { Weight } \\
\text { gain } \\
(\mathrm{n}=60)\end{array}$ & \multicolumn{2}{|c|}{$\begin{array}{l}\text { Age and sex- } \\
\text { adjusted }\end{array}$} & $\begin{array}{c}\text { No } \\
\text { weight } \\
\text { gain } \\
(\mathrm{n}=87)\end{array}$ & $\begin{array}{c}\text { Weight } \\
\text { gain } \\
(\mathrm{n}=19)\end{array}$ & \multicolumn{2}{|c|}{ Age and sex-adjusted } \\
\hline $\begin{array}{l}\text { Under } \\
\text { graduate }\end{array}$ & 251 & 36 & $\begin{array}{c}0.96 \\
{[0.73-1.28]}\end{array}$ & & 93 & 19 & $\begin{array}{c}1.12 \\
{[0.74-1.68]}\end{array}$ & & 21 & 6 & $\begin{array}{c}1.17 \\
{[0.55-2.51]}\end{array}$ & \\
\hline $\begin{array}{l}\text { Post } \\
\text { graduate }\end{array}$ & 268 & 30 & 1 & & 95 & 13 & 1 & & 30 & 6 & 1 & \\
\hline \multicolumn{13}{|l|}{$\begin{array}{l}\text { Excess weight }{ }^{3} \\
\text { before cancer } \\
\text { diagnosis }\end{array}$} \\
\hline No & 559 & 71 & 1 & & 226 & 34 & 1 & & 60 & 12 & 1 & \\
\hline Yes & 361 & 60 & $\begin{array}{c}1.64 \\
{[1.12-2.42]}\end{array}$ & 0.01 & 99 & 26 & $\begin{array}{c}1.91 \\
{[1.08-3.39]}\end{array}$ & 0.03 & 27 & 7 & $\begin{array}{c}1.15 \\
{[0.39-3.40]}\end{array}$ & 0.8 \\
\hline \multicolumn{13}{|l|}{$\begin{array}{l}\text { Physical } \\
\text { activity } \\
\text { after cancer } \\
\text { diagnosis }^{4}\end{array}$} \\
\hline $\begin{array}{l}\text { Physically } \\
\text { active } \\
\text { (moderate- } \\
\text { to-intense) }\end{array}$ & 582 & 68 & 1 & 0.04 & 218 & 34 & 1 & 0.2 & 54 & 13 & 1 & 0.7 \\
\hline $\begin{array}{l}\text { Low } \\
\text { physical } \\
\text { activity }\end{array}$ & 149 & 33 & $\begin{array}{c}1.28 \\
{[1.01-1.64]}\end{array}$ & & 44 & 13 & $\begin{array}{c}1.30 \\
{[0.89-1.89]}\end{array}$ & & 19 & 3 & $\begin{array}{c}0.85 \\
{[0.42-1.75]}\end{array}$ & \\
\hline $\begin{array}{l}\text { Energy intake } \\
\text { variation } \\
\text { before / } \\
\text { after cancer } \\
\text { diagnosis }\end{array}$ & & & & $0.3^{5}$ & & & & $0.9^{5}$ & & & & $0.4^{5}$ \\
\hline $\begin{array}{l}<-100 \mathrm{kcal} / \\
\text { day }\end{array}$ & 255 & 39 & $\begin{array}{c}1.16 \\
{[0.89-1.54]}\end{array}$ & & 90 & 17 & $\begin{array}{c}1.03 \\
{[0.66-1.60]}\end{array}$ & & 28 & 7 & $\begin{array}{c}1.42 \\
{[0.30-3.19]}\end{array}$ & \\
\hline $\begin{array}{l}{[-100-} \\
+100] \mathrm{kcal} / \\
\text { day }\end{array}$ & 141 & 17 & 1 & & 66 & 9 & 1 & & 20 & 2 & 1 & \\
\hline $\begin{array}{l}>+100 \mathrm{kcal} / \\
\text { day }\end{array}$ & 198 & 19 & $\begin{array}{c}0.90 \\
{[0.63-1.26]}\end{array}$ & & 51 & 10 & $\begin{array}{c}1.09 \\
{[0.66-1.80]}\end{array}$ & & 19 & 2 & $\begin{array}{c}0.84 \\
{[0.30-2.32]}\end{array}$ & \\
\hline \multicolumn{13}{|l|}{ Smoking status } \\
\hline $\begin{array}{l}\text { Never } \\
\text { smoker }\end{array}$ & 831 & 99 & 1 & & 291 & 47 & 1 & & 79 & 16 & 1 & \\
\hline $\begin{array}{l}\text { Former } \\
\text { smoker } \\
\text { (stopped } \\
\text { at cancer } \\
\text { diagnosis) }\end{array}$ & 18 & 12 & $\begin{array}{c}4.31 \\
{[1.99-9.35]}\end{array}$ & 0.005 & 6 & 5 & $\begin{array}{c}3.95 \\
{[1.14-} \\
13.67]\end{array}$ & 0.07 & 0 & 0 & NA & NA \\
\hline $\begin{array}{l}\text { Smoker } \\
\text { after cancer } \\
\text { diagnosis }\end{array}$ & 71 & 20 & $\begin{array}{c}1.96 \\
{[1.13-3.40]}\end{array}$ & 0.9 & 28 & 8 & $\begin{array}{c}1.45 \\
{[0.61-3.43]}\end{array}$ & 0.5 & 8 & 3 & $\begin{array}{c}1.77 \\
{[0.41-7.64]}\end{array}$ & 0.4 \\
\hline
\end{tabular}

OR: odds ratio; CI: confidence interval; NA: not applicable.

${ }^{1}$ Weight gain $\geq 5 \%$ of the weight before diagnosis.

${ }^{2}$ At baseline, i.e. at inclusion in the NutriNet-Santé cohort study (before cancer diagnosis).

${ }^{3} \mathrm{BMI} \geq 25 \mathrm{~kg} / \mathrm{m}^{2}$.

${ }^{4}$ From the validated IPAQ questionnaire.

${ }^{5} \mathrm{p}$-trend. 


\section{DISCUSSION}

To our knowledge, this large cohort study was the first to investigate weight variations between before and after cancer diagnosis with anthropometric data collected prospectively, and a follow-up beginning in average $2 y$ before diagnosis. Different weight trajectories were observed according to cancer locations. While weight loss was reported in many colorectal cancer patients, a substantial proportion of breast and skin cancer patients gained weight. Sociodemographic and economic factors appeared as important determinants of weight gain: patients with lower educational level or lower monthly income, women, and those aged below 60y were more likely to experience moderate-to-severe weight gain. Physical activity after diagnosis was associated with lower weight gain. In contrast, initial excess weight and smoking cessation after cancer diagnosis were strongly associated with weight gain. In breast cancer patients, induced menopause was also strongly associated with weight gain, while tumor characteristics and treatments did not appear as major predictors of weight gain in this study.

\section{Weight variations according to cancer location}

A substantial proportion (23\%) of colorectal cancer patients experienced moderate-to-severe weight loss in this study, consistent with previous literature $[6,36]$. This may be due to the fact that digestive function is directly affected in this pathology. A recent review showed that this weight loss has devastating effects on patients' selfimage, quality of life, and survival [6].

In contrast, $16 \%$ of breast cancer cases experienced moderate-to-severe weight gain in our cohort. Consistently, many studies observed weight gain after female breast cancer diagnosis in Western countries [8$13,28,37$, with varying proportions of patients gaining weight. In a recent French survey [8], $60 \%$ of the cohort gained weight after breast diagnosis. A systematic review published in 2011 indicated that $50-96 \%$ of women experienced weight gain during breast cancer treatment [12]. However, most of these studies considered cancer diagnosis as baseline, while this potentially corresponds to a period of strong weight fluctuation [11]. Indeed, it has been shown that patients who gained weight after cancer in a long-term basis were likely to first lose weight just before/around diagnosis [11]. Thus, in the present study, we excluded anthropometric data collected 3 months before and 6 months after (12 and 24 months in sensitivity analyses) cancer diagnosis, in order to focus on stabilized periods.

In our study, we did not observe any association between clinical characteristics and treatments of breast tumors and the risk of weight gain. These results should be considered with caution since statistical power was limited for several parameters. However, these results were consistent with previous studies that showed no association between tumor stage $[9,11]$ or hormone receptor status [13] and weight gain after breast cancer. In contrast, other studies suggested that mixed (+/-) receptor status and more advanced tumor stage could increase the risk of weight gain [10, 13, 37]. Concerning the association between cancer treatments and weight change, mixed results have been reported $[8,12,13]$. In particular, adjuvant therapy has been linked to a higher risk of weight gain in some studies [12, 13, 27] but not in others $[28,29,38]$.

Breast cancer women with induced menopause (caused by ablation of the uterus and/or both ovaries, by radiotherapy or by chemotherapy) had a drastically increased risk of weight gain. This phenomenon, already known in the general population [39], has been described in the specific context of breast cancer in an American study where $70 \%$ of women being treated with ovarian suppression reported moderate-to-severe weight gain [40].

A substantial proportion (18\%) of skin cancer patients also experienced moderate-to-severe weight gain in our study. To our knowledge, this has not been investigated in previous literature and deserves confirmation in future studies. One of the explanations may be that patients diagnosed with skin cancer receive medical advice to avoid sun exposure, which could limit their practice of outdoor physical activity.

\section{Weight variations according to socio- demographic, economic and lifestyle characteristics}

This study suggests that sociodemographic and economic factors are associated with weight gain between before and after cancer diagnosis. Subjects with lower educational level were more likely to gain weight, consistent with a previous study on breast cancer patients [13]. Lower monthly income was also associated with higher risk of weight gain in our study, but not independently from educational level. In developed countries, education is generally inversely associated with overweight and obesity via adult socioeconomic status (e.g. income and occupation), but also via health literacy, health behaviors, and sense of control and empowerment [41]. The fact that women were more likely to gain weight than men after cancer diagnosis is probably driven by our results regarding weight gain in breast cancer patients. In our study, we found that subjects who were aged $\leq 60$ at cancer diagnosis were more likely to gain weight than their older counterparts, as shown in others studies $[10$, $13,14,38]$. This may be due to the fact that older patients are more prone to malnutrition and subsequent weight loss [42].

Consistent with previous findings [43], patients already overweight before diagnosis were more likely to gain weight, suggesting that weight management issues 
track after cancer onset. Interestingly, we showed that smoking cessation after diagnosis was strongly associated with weight gain. This phenomenon is well described in the general population $[44,45]$, but is of particular importance in cancer patients, who are strongly advised to stop smoking after diagnosis. Patients who were smoking after cancer diagnosis were also at higher risk of weight gain compared to never smoker consistent with another study [10]. Moderate-to-intense physical activity after diagnosis was associated with lower weight gain in sex and age-adjusted models. This point is debated in the literature, some studies suggesting an impact of decreasing physical activity on weight gain $[25,46]$, while a recent review in prostate cancer patients concluded that exercise alone did not lead to weight loss [47].

Strengths of this study pertained to a large population-based cohort with incident cancer cases, prospective anthropometric data collected before and after cancer diagnosis and detailed information on sociodemographic, economic, lifestyle and clinical parameters.

Several limitations should be acknowledged. First, caution is needed in extrapolating our results to all French cancer cases, since the NutriNet-Santé study involved volunteers who accepted to participate in a survey on nutrition and health. Indeed, compared to national estimates, the NutriNet-Santé study included more women and individuals belonging to higher socioprofessional categories, as often observed in populationbased observational cohorts [48]. Besides, despite lower incidence rates, main cancer locations represented in our cohort were same as in the general population (breast, prostate, colorectal) [49] was similar in our cohort. As in all observational cohorts some cancer cases may have been missed. We hypothesize that such cancer cases may have had a poorer prognosis; therefore this study may have overestimated the proportion of cancers with better prognosis. Moreover, a number of cancer cases were excluded due to missing weight data before or after diagnosis and some of their characteristics (cancer location) differed from those of included cases. Furthermore, even if we have tested all relevant factors available in our cohort; some others (such as psychological factors) were not taken into account. Next, weight and height were self-reported, thus classification bias could not be excluded. However, in a previous validation study on 199 subjects, we showed that self-reported weight and height data from the NutriNet-Santé web-based study were valid and strongly correlated with anthropometric data measured by study staff [50]. Finally, while medical records were available for validation of all cancer cases, exhaustive clinical data were not systematically recorded in these files. These missing values for clinical factors in some patients may have impaired our ability to detect some of the hypothesized associations.

In conclusion, this large cohort of cancer patients provided original prospective results on weight variation between before and after cancer diagnosis, highlighting different weight trajectories. While weight loss was widespread after cancer diagnosis (especially for digestive cancers), a substantial proportion of cancer survivors (especially breast cancers) experienced moderate-tosevere weight gain. More than tumor characteristics or treatments, socio-demographic and economic factors appeared to influence the risk of weight gain, illustrating social inequalities in health (higher risk in patients with lower educational level or lower income). Since excess weight has been recognized as a key modifiable risk factor for recurrence and second cancer, efforts are needed to encourage cancer survivors to achieve or maintain healthy body weight [22]. Results of the present study provide insights to identify and target the sub-groups of patients who are more specifically at-risk of moderate-to-severe weight gain.

\section{MATERIALS AND METHODS}

\section{The NutriNet-Santé cohort}

The NutriNet-Santé study is a large web-based cohort launched in May 2009 to evaluate the determinants of eating behavior and the relationships between nutrition and chronic disease risk in the French general population. Participants are recruited by vast multimedia campaigns. Inclusion criteria are: age $\geq 18 \mathrm{y}$ and access to the Internet. Participants register and are followed-up online using a dedicated website (www.etude-nutrinet-sante.fr). The recruitment is still ongoing. The NutriNet-Santé study was approved by the Institutional Review Board of the French Institute for Health and Medical Research (IRB Inserm $n^{\circ} 0000388$ FWA00005831) and the "Commission Nationale de l'Informatique et des Libertés" (CNIL $\mathrm{n}^{\circ} 908450$ and $\mathrm{n}^{\circ}$ 909216).

\section{Data collection}

At baseline and each year thereafter, participants completed a set of five self-administered web-based questionnaires on socio-demographic and lifestyle characteristics (sex, age, living area, employment status, monthly income per household unit, educational level, and smoking status), anthropometrics (weight and height), dietary intake (3 non-consecutive 24-h dietary records), physical activity (validated IPAQ questionnaire [30]), and health status. All these instruments have been tested against traditional assessment methods (paper-andpencil questionnaires or interview by a dietitian) [31-33]. Intermediate self-administered questionnaires were also used to collect weight, height and dietary data every 6 months. In women, information regarding menopause (date, natural or induced, and hormonal treatment) was obtained from health questionnaires. 


\section{Case ascertainment}

Participants self-declared any cancer diagnosis during follow-up through regular questionnaires every 6 months and a permanent web-interface. Pathological reports were used by an independent physician expert committee for validation. All cancer cases were validated and classified using the International Chronic Diseases Classification, 10th Revision, Clinical Modification (ICD-10) [34]. All first incident cancers were considered as cases in this study, except basal cell carcinoma (not considered as cancer).

For the four main cancer locations represented in this study (breast, prostate, skin, colon-rectum), tumor characteristics and treatments were extracted from medical records: for breast cancer: tumor size, lymph node status, tumor type (invasive or in situ), estrogen and progesterone receptor status, HER2 status, Ki67 and treatment (chemotherapy and/or hormone therapy); for prostate cancer: tumor size, lymph node status, PSA, Gleason score and treatment (chemotherapy, radiotherapy and/or hormone therapy); for skin cancer: melanoma: Breslow index and Clark level and squamous cell carcinoma: type of tumor (invasive or in situ); for colorectal cancer: tumor size, lymph node status and treatment. Given the low number of advanced stages for each tumor location, using TNM/UICC stages was not discriminating, thus, patients were classified into two categories (favorable prognosis/ poor prognosis) according to clinically pertinent factors, as described in footnotes to Table 1 .

\section{Statistical analysis}

From the 1704 cancer cases diagnosed in the NutriNet-Santé study between May 2009 and June 2015 and with at least 6 months of follow-up after diagnosis, 1426 cases were first incident cancers. We excluded 350 patients with missing BMI before or after cancer diagnosis and 25 pregnant women, leaving 1051 cancer cases for analysis.

For each subject, mean weight before (respectively after) diagnosis was calculated as the average of all weight data before (respectively after) cancer diagnosis. Weight data declared in the timeframe [-3 months before; +6 months after] cancer diagnosis were excluded from the calculation, in order to focus on stable periods. Relative difference was calculated as (mean weight after diagnosis - mean weight before diagnosis)/mean weight before diagnosis*100. BMI was calculated as weight $(\mathrm{kg}) /$ height $(m)^{2}$. Similarly, variation in mean daily energy intake between before and after diagnosis was calculated. Baseline socio-demographic data were used for the present analysis. Multiple imputations were applied for all covariates with missing data (monthly incomes, educational level, physical activity after cancer diagnosis, energy intake variation before / after cancer diagnosis and cancer prognosis) [35].

Weight before and after cancer diagnosis was compared by paired Student's t-test. These variations were compared between sex, cancer location and cancer prognosis by ANOVA. Weight variations were classified into 3 categories: "moderate-to-severe weight loss" (weight loss $\geq 5 \%$ of initial weight), "moderate-to-severe weight gain" (weight gain $\geq 5 \%$ of initial weight), and "no major weight variation" otherwise. Weight evolutions were compared between sex, cancer location and cancer prognostic by Chi-square tests.

Age and sex-adjusted unconditional logistic regression analyses were used to investigate the associations between moderate-to-severe weight gain and socio-demographic and economic factors (sex, age, living area, professional activity, monthly income, and educational level), and lifestyle factors (excess weight before cancer diagnosis, variation of daily energy intake, variation of smoking status before/after diagnosis, and physical activity after diagnosis). This analysis was conducted for overall cancer and breast cancer specifically (main cancer location in the cohort). We also tested two-way interactions between all these sociodemographic, economic and lifestyle parameters, and cancer prognosis.

In breast cancer cases, unconditional logistic regression analyses adjusted for above listed factors were used to investigate the associations between moderateto-severe weight gain and tumor characteristics and treatments, and menopausal status and cause.

Sensitivity analyses were performed by excluding subjects with cancer recurrence or second primary cancer during follow-up, and by excluding anthropometric data collected less than 1 year or 2 years after cancer diagnosis.

P-value $<0.05$ was considered statistically significant. All tests were two-sided. Analyses were carried out with SAS 9.3 (SAS Institute Inc, Cary, NC, USA).

\section{Author contributions}

The authors' responsibilities were as follows- $\mathrm{PF}$ and Mathilde Touvier: designed the research; PF wrote the manuscript; SH, PG, NDP and Mathilde Touvier: conducted the research; PF: performed the statistical analysis; LZ, PB, MT, NDP, VP, SH, PG, PC, HH, PLM, BS, RG, MD, Mathilde Touvier: contributed to the data interpretation and revised each draft of the manuscript for important intellectual content; PF and Mathilde Touvier: had primary responsibility for the final content of the manuscript; and all authors: read and approved the final manuscript. None of the authors reported a conflict of interest related to the study. The funders had no role 
in the design, implementation, analysis, or interpretation of data.

\section{ACKNOWLEDGMENTS}

The authors thank Ludivine Ursule for her assistance to the medical team. We also thank Younes Esseddik, Paul Flanzy, Mohand Ait Oufella, Yasmina Chelghoum, Than Duong Van and Mac Rakotondrazafy (computer scientists); and Nathalie Arnault, Véronique Gourlet, Dr. Fabien Szabo, Charlie Ménard, Laurent Bourhis, and Stephen Besseau (data-manager/biostatisticians) for their technical contribution to the NutriNet-Santé study. We thank all the volunteers of the NutriNet-Santé cohort. This project has been conducted in the framework of the NACRe network (National network on Nutrition and Cancer).

\section{CONFLICTS OF INTEREST}

The authors declare that they have no conflicts of interest.

\section{FUNDING}

The present work was supported by the 2013 Research Prize from the French Nutrition Society and the French National Cancer Institute (no. DEPREV14-027). Philippine Fassier and Mélanie Deschasaux were funded by a PhD grant from the Cancéropôle Ile-de-France (public funding from the Paris region). The NutriNetSanté study was supported by the following public institutions: Ministère de la Santé, Institut de Veille Sanitaire (InVS), Institut National de la Prévention et de l'Education pour la Santé (INPES), Fondation pour la Recherche Médicale (FRM), Institut National de la Santé et de la Recherche Médicale (INSERM), Institut National de la Recherche Agronomique (INRA), Conservatoire National des Arts et Métiers (CNAM) and Université Paris 13.

\section{REFERENCES}

1. Ferlay J, Soerjomataram I, Dikshit R, Eser S, Mathers C, Rebelo M, Parkin DM, Forman D, Bray F. Cancer incidence and mortality worldwide: sources, methods and major patterns in GLOBOCAN 2012. Int J Cancer; 2013.

2. Sanchez-Lara K, Ugalde-Morales E, Motola-Kuba D, Green D. Gastrointestinal symptoms and weight loss in cancer patients receiving chemotherapy. Br J Nutr. 2013; 109:894-7.

3. Garth AK, Newsome CM, Simmance N, Crowe TC. Nutritional status, nutrition practices and post-operative complications in patients with gastrointestinal cancer. J Hum Nutr Diet. 2010; 23:393-401.

4. Hebuterne X, Lemarie E, Michallet M, de Montreuil CB, Schneider SM, Goldwasser F. Prevalence of malnutrition and current use of nutrition support in patients with cancer. JPEN J Parenter Enteral Nutr. 2014; 38:196-204.

5. Van Cutsem E, Arends J. The causes and consequences of cancer-associated malnutrition. Eur J Oncol Nurs. 2005; 9: S51-S63.

6. Bapuji SB, Sawatzky JA. Understanding weight loss in patients with colorectal cancer: a human response to illness. Oncol Nurs Forum. 2010; 37:303-10.

7. Reddy SM, Sadim M, Li J, Yi N, Agarwal S, Mantzoros CS, Kaklamani VG. Clinical and genetic predictors of weight gain in patients diagnosed with breast cancer. Br J Cancer. 2013; 109:872-81.

8. Tredan O, Bajard A, Meunier A, Roux P, Fiorletta I, Gargi T, Bachelot T, Guastalla JP, Lallemand Y, Faure C, Perol $\mathrm{D}$, Bachmann P. Body weight change in women receiving adjuvant chemotherapy for breast cancer: a French prospective study. Clin Nutr. 2010; 29:187-91.

9. Yaw YH, Shariff ZM, Kandiah M, Mun CY, Yusof RM, Othman Z, Saibul N, Weay YH, Hashim Z. Weight changes and lifestyle behaviors in women after breast cancer diagnosis: a cross-sectional study. BMC Public Health. 2011; 11:309.

10. Chen X, Lu W, Gu K, Chen Z, Zheng Y, Zheng W, Shu $\mathrm{XO}$. Weight change and its correlates among breast cancer survivors. Nutr Cancer. 2011; 63:538-48.

11. Yaw YH, Kandiah M, Shariff ZM, Mun CY, Hashim Z, Yusof RM, Othman Z, Saibul N, Weay YH. Pattern of weight changes in women with breast cancer. Asian Pac J Cancer Prev. 2010; 11:1535-40.

12. Vance V, Mourtzakis M, McCargar L, Hanning R. Weight gain in breast cancer survivors: prevalence, pattern and health consequences. Obes Rev. 2011; 12:282-94.

13. Gu K, Chen X, Zheng Y, Chen Z, Zheng W, Lu W, Shu $\mathrm{XO}$. Weight change patterns among breast cancer survivors: results from the Shanghai breast cancer survival study. Cancer Causes Control. 2010; 21:621-9.

14. Timilshina N, Breunis H, Alibhai SM. Impact of androgen deprivation therapy on weight gain differs by age in men with nonmetastatic prostate cancer. J Urol. 2012; 188:2183-8.

15. Kim HS, Moreira DM, Smith MR, Presti JC Jr, Aronson WJ, Terris MK, Kane CJ, Amling CL, Freedland SJ. A natural history of weight change in men with prostate cancer on androgen-deprivation therapy (ADT): results from the Shared Equal Access Regional Cancer Hospital (SEARCH) database. BJU Int. 2011; 107:924-8.

16. Chan DS, Vieira AR, Aune D, Bandera EV, Greenwood DC, McTiernan A, Navarro RD, Thune I, Vieira R, Norat T. Body mass index and survival in women with breast 
cancer-systematic literature review and meta-analysis of 82 follow-up studies. Ann Oncol. 2014; 25:1901-14.

17. Bonn SE, Wiklund F, Sjolander A, Szulkin R, Stattin P, Holmberg E, Gronberg H, Balter K. Body mass index and weight change in men with prostate cancer: progression and mortality. Cancer Causes Control. 2014; 25:933-43.

18. Caan BJ, Kwan ML, Shu XO, Pierce JP, Patterson RE, Nechuta SJ, Poole EM, Kroenke CH, Weltzien EK, Flatt SW, Quesenberry CP Jr, Holmes MD, Chen WY. Weight change and survival after breast cancer in the after breast cancer pooling project. Cancer Epidemiol Biomarkers Prev. 2012; 21:1260-71.

19. McTiernan A, Irwin M, Vongruenigen V. Weight, physical activity, diet, and prognosis in breast and gynecologic cancers. J Clin Oncol. 2010; 28:4074-80.

20. Nechuta S, Chen WY, Cai H, Poole EM, Kwan ML, Flatt SW, Patterson RE, Pierce JP, Caan BJ, Shu XO. A pooled analysis of post-diagnosis lifestyle factors in association with late estrogen-receptor positive breast cancer prognosis. Int J Cancer. 2015; 138:2088-97.

21. Playdon MC, Bracken MB, Sanft TB, Ligibel JA, Harrigan $\mathrm{M}$, Irwin ML. Weight gain after breast cancer diagnosis and all-cause mortality: systematic review and meta-analysis. J Natl Cancer Inst. 2015; 107.

22. Alfano CM, Bluethmann SM, Tesauro G, Perna F, AgursCollins T, Elena JW, Ross SA, O'Connell M, Bowles HR, Greenberg D, Nebeling L. NCI funding trends and priorities in physical activity and energy balance research among cancer survivors. J Natl Cancer Inst. 2016; 108.

23. Demark-Wahnefried W, Rogers LQ, Alfano CM, Thomson CA, Courneya KS, Meyerhardt JA, Stout NL, Kvale E, Ganzer H, Ligibel JA. Practical clinical interventions for diet, physical activity, and weight control in cancer survivors. CA Cancer J Clin. 2015; 65:167-89.

24. Druesne-Pecollo N, Touvier M, Barrandon E, Chan DS, Norat T, Zelek L, Hercberg S, Latino-Martel P. Excess body weight and second primary cancer risk after breast cancer: a systematic review and meta-analysis of prospective studies. Breast Cancer Res Treat. 2012; 135:647-54.

25. Wijndaele K, Lynch BM, Owen N, Dunstan DW, Sharp $\mathrm{S}$, Aitken JF. Television viewing time and weight gain in colorectal cancer survivors: a prospective population-based study. Cancer Causes Control. 2009; 20:1355-62.

26. Goodwin PJ, Ennis M, Pritchard KI, McCready D, Koo J, Sidlofsky S, Trudeau M, Hood N, Redwood S. Adjuvant treatment and onset of menopause predict weight gain after breast cancer diagnosis. J Clin Oncol. 1999; 17:120-9.

27. Gross AL, May BJ, Axilbund JE, Armstrong DK, Roden RB, Visvanathan K. Weight change in breast cancer survivors compared to cancer-free women: a prospective study in women at familial risk of breast cancer. Cancer Epidemiol Biomarkers Prev. 2015; 24:1262-9.
28. Han HS, Lee KW, Kim JH, Kim SW, Kim IA, Oh DY, Im SA, Bang SM, Lee JS. Weight changes after adjuvant treatment in Korean women with early breast cancer. Breast Cancer Res Treat. 2009; 114:147-53.

29. Vagenas D, DiSipio T, Battistutta D, Demark-Wahnefried W, Rye S, Bashford J, Pyke C, Saunders C, Hayes SC. Weight and weight change following breast cancer: evidence from a prospective, population-based, breast cancer cohort study. BMC Cancer. 2015; 15:28.

30. Craig CL, Marshall AL, Sjostrom M, Bauman AE, Booth ML, Ainsworth BE, Pratt M, Ekelund U, Yngve A, Sallis JF, Oja P. International physical activity questionnaire: 12-country reliability and validity. Med Sci Sports Exerc. 2003; 35:1381-95.

31. Vergnaud AC, Touvier M, Mejean C, Kesse-Guyot E, Pollet C, Malon A, Castetbon K, Hercberg S. Agreement between web-based and paper versions of a socio-demographic questionnaire in the NutriNet-Sante study. Int J Public Health. 2011; 56:407-17.

32. Touvier M, Kesse-Guyot E, Mejean C, Pollet C, Malon A, Castetbon K, Hercberg S. Comparison between an interactive web-based self-administered $24 \mathrm{~h}$ dietary record and an interview by a dietitian for large-scale epidemiological studies. Br J Nutr. 2011; 105:1055-64.

33. Touvier M, Mejean C, Kesse-Guyot E, Pollet C, Malon A, Castetbon K, Hercberg S. Comparison between web-based and paper versions of a self-administered anthropometric questionnaire. Eur J Epidemiol. 2010; 25:287-96.

34. International Classification of Diseases and Related Health Problems.10th revision: Geneva, Switzerland: WHO. 1993.

35. Sterne JA, White IR, Carlin JB, Spratt M, Royston P, Kenward MG, Wood AM, Carpenter JR. Multiple imputation for missing data in epidemiological and clinical research: potential and pitfalls. BMJ. 2009; 338:b2393.

36. Attar A, Malka D, Sabate JM, Bonnetain F, Lecomte T, Aparicio T, Locher C, Laharie D, Ezenfis J, Taieb J. Malnutrition is high and underestimated during chemotherapy in gastrointestinal cancer: an AGEO prospective cross-sectional multicenter study. Nutr Cancer. 2012; 64:535-42.

37. Irwin ML, McTiernan A, Baumgartner RN, Baumgartner KB, Bernstein L, Gilliland FD, Ballard-Barbash R. Changes in body fat and weight after a breast cancer diagnosis: influence of demographic, prognostic, and lifestyle factors. J Clin Oncol. 2005; 23:774-82.

38. Cancer: life two years after diagnosis-VICAN2. INCa (French National Cancer Institute). 2014.

39. Barton DL, Ganz PA. Symptoms: menopause, infertility, and sexual health. Adv Exp Med Biol. 2015; 862:115-41.

40. Leining MG, Gelber S, Rosenberg R, Przypyszny M, Winer EP, Partridge AH. Menopausal-type symptoms in young breast cancer survivors. Ann Oncol. 2006; 17:1777-82. 
41. Cohen AK, Rai M, Rehkopf DH, Abrams B. Educational attainment and obesity: a systematic review. Obes Rev. 2013; 14:989-1005.

42. Sorbye LW. Cancer in home care: unintended weight loss and ethical challenges. A cross-sectional study of older people at 11 sites in Europe. Arch Gerontol Geriatr. 2011; 53:64-9.

43. Seible DM, Gu X, Hyatt AS, Beard CJ, Choueiri TK, Efstathiou JA, Miyamoto DT, Mitin T, Martin NE, Sweeney CJ, Trinh QD, Beckman JA, Basaria S, et al. Weight gain on androgen deprivation therapy: which patients are at highest risk? Urology. 2014; 83:1316-21.

44. Robertson L, McGee R, Hancox RJ. Smoking cessation and subsequent weight change. Nicotine Tob Res. 2014; 16:867-71.

45. Taniguchi C, Tanaka H, Oze I, Ito H, Saka H, Tachibana K, Tokoro A, Nozaki Y, Nakamichi N, Suzuki Y, Suehisa H, Sakakibara H. Factors associated with weight gain after smoking cessation therapy in Japan. Nurs Res. 2013; 62:414-21.
46. Nissen MJ, Shapiro A, Swenson KK. Changes in weight and body composition in women receiving chemotherapy for breast cancer. Clin Breast Cancer. 2011; 11:52-60.

47. Mohamad H, McNeill G, Haseen F, N'Dow J, Craig LC, Heys SD. The effect of dietary and exercise interventions on body weight in prostate cancer patients: a systematic review. Nutr Cancer. 2015; 67:43-60.

48. Andreeva VA, Salanave B, Castetbon K, Deschamps V, Vernay M, Kesse-Guyot E, Hercberg S. Comparison of the sociodemographic characteristics of the large NutriNet-Sante e-cohort with French Census data: the issue of volunteer bias revisited. J Epidemiol Community Health. 2015; 69:893-8.

49. Les cancers en France en 2015 : l'essentiel des faits et chiffres. http://www.e-cancer.fr/Expertises-et-publications/ Catalogue-des-publications/Les-cancers-en-France-en2015-L-essentiel-des-faits-et-chiffres. 2016.

50. Lassale C, Peneau S, Touvier M, Julia C, Galan P, Hercberg $\mathrm{S}$, Kesse-Guyot E. Validity of web-based self-reported weight and height: results of the Nutrinet-Sante study. J Med Internet Res. 2013; 15:e152. 